Serve, assim, a hipótese, para melhor esclarecer os limites de nossa proposta, que $\operatorname{diz}$ respeito apenas às relações jurídicas continuativas.

Como já se observou, o voto vencido afastava o princípio da legalidade, para que prevalecesse a justiça.

Embora o tema da justiça fuja aos propósitos do presente trabalho, ousamos pôr em dúvida sua assertiva de que houve "flagrante injustiça".

O que há de mais importante em um concurso é a rigorosa observância das normas que o disciplinam. De modo algum se admite a "alteração das regras do jogo", depois de se verificar que estes ou aqueles candidatos resultaram eliminados. Os que venceram todas as provas têm direito a prosseguir no concurso já sem a concorrência dos reprovados. Se a Administração estatui que certa prova "não valeu", para dar nova oportunidade a alguns assim favorecidos, há ilícito administrativo. Deixa de haver tratamento igual de todos os candidatos, quando se dispensam alguns da exigência de aprovação em prova exigida de todos os outros.

Do ponto de vista de justiça, a situação não muda, se a "alteração das regras do jogo" decorre de sentença.

Claro que o Judiciário pode anular ou dispensar prova, em atenção ao princípio da legalidade. Mas, sempre visualizando a situação do ponto de vista dos prejudicados pela decisão judicial: seriam prejudicados, primeiro, pela invocação do princípio da legalidade, com a reintrodução no concurso de candidatos que, observado o edital, já estariam afastados; depois, pela desconsideração da legalidade, em especial pelo desrespeito à coisa julgada, com a reintrodução de ainda outro, agora com invocação de princípio de justiça.

"Que estranho poder tem esse candidato!", bem poderiam exclamar, "de afastar prova de nós exigida, com invocação do princípio da legalidade, e de afastar o mesmo princípio, quando o prejudicava!"

Evidencia-se, assim, que a "flagrante injustiça", apontada pelo vencido, somente é sentida na medida em que nos identificamos com o autor da ação; não quando consideramos os fatos do ponto de vista do todo maior dos demais concorrentes. Trata-se, pois, de uma justiça meramente subjetiva, em oposição à justiça objetiva, entendida esta como "conformidade de uma relação interpessoal com o bem comum", tal como a definia o jusfilósofo gaúcho ARMANDO CÂMARA.

Se valessem considerações de justiça subjetiva, bem que poderíamos nos colocar no lugar daquele concorrente ausente, que deixaria de ser nomeado, porque preterido uma vez por causa da lei, e outra contra a lei.

No plano legal, a ação rescisória não se presta à correção de injustiça da sentença. Com mais forte razão, não se pode dispensar a própria ação rescisória, para corrigir injustiça de sentença anterior. Se, num caso, invocamos o princípio da isonomia, para afastar essas regras, como aplicá-las nos outros, sem quebra do mesmo princípio da isonomia? E, se as afastamos em todos os casos, deixa de haver "coisa julgada", com todos os benefícios que dela decorrem.

\title{
Dimensões da Independência do Poder Judiciário
}

\author{
Fosé eNéri da Pilveina \\ Ministro do Supremo Tribunal Federal
}

Aula Magna proferida na Faculdade de Direito da Universidade Federal do Rio Grande do Sul, a 26.04.1999, em Porto Alegre, RS.

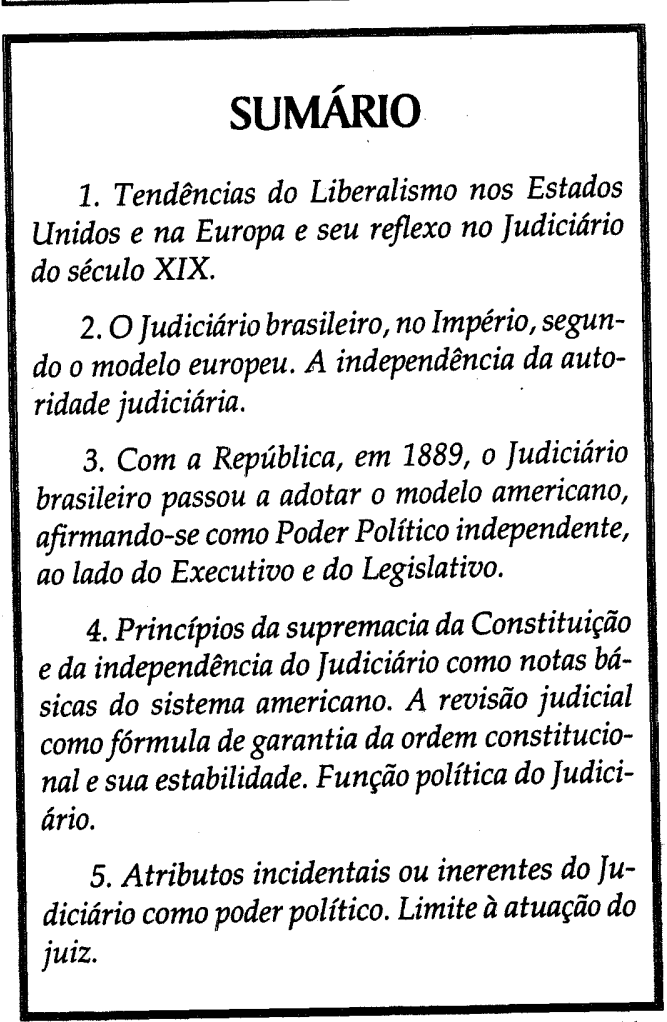

6. Autonomia administrativa e financeira como nova dimensão da independência do Poder Judiciário, desde a Constituição de 1988. Autonomia administrativa e unidade do Poder Judiciário. Necessidade de um Conselho Nacional de Administração da Justiça.

7. A legitimidade do Poder Judiciário expressa em disciplina constitucional.

8. A visualização teleológica do Poder Judiciário, enquanto instrumento de efetiva realização da cidadania e de real garantia dos direitos.

9. Universalidade do controle jurisdicional. O processo e sua instrumentalidade. O processo e a justiça social. O acesso à Justiça para todos.

10. Os pobres e o acesso d̀ justiça. A essencialidade da Defensoria Pública, na administração da Justiça.

11. O controle dos atos do Poder Judiciário. O controle e o princípio da independência do Judiciário.

12. Reforma constitucional do Judiciário e a cláusula pétrea do art. $60, \S 4^{\circ}$, III, da Constituição. Limites materiais.

13. A independência do Judiciário como valor indisponivel. 
Ty É possível afirmar que, desde o último quartel do século XVIII, com as Revoluções americana e francesa, na esteira do pensamento liberal que ganhou curso, a concepção de uma ordem constitucional não prescinde de dois componentes: separação de poderes e garantia de direitos. O famoso art. 16, da Declaração dos Direitos do Homem e do Cidadão, de 1789, da Revolução Francesa, assentava: "Toute societé dans laquelle la garantie des droits n'est pas assurée, ni la séparation des pouvoirs determinée, n'a point de constitution". Na lição de BURDEAU, a constituição foi, historicamente, no Ocidente, um instrumento de limitação do poder.

ÉDOUARD LABOULAYE, versan: do, em 1866, sobre o Judiciário, na Constituição americana, ponderou que foram os americanos os primeiros "a fazer do Poder Judiciário um verdadeiro poder político; os primeiros a compreender o papel da justiça num país livre; os primeiros a encontrar esta nova verdade, até aqui pouco compreendida na Europa". Observa, noutro passo: "Jamais, entre nós, a justiça foi um poder político; ela foi sempre um ramo da administração, uma dependência do Poder Exe. cutivo, uma função do governo, e uma função subalterna". Referindo-se, porém, ao caráter desse Poder, na Constituição ame. ricana, acrescenta: "Estabeleceu-se ali um Poder Judiciário independente, um Poder que, colocado entre as leis do Congresso e a Constituição, tem o direito de afirmar: 'Esta lei é contrária à Constituição, e, conseqüentemente, é nula'. (...). Não há, aí, nenhum motivo de perturbação da ordem, mas, bem pelo contrário, uma das maiores causas de paz e de quietude social" (apud
História dos Estados Unidos. Terceira época: A Constituição dos Estados Unidos (1866). Tradução de L. NEQUETE, inserto em $O$ Poder Judiciário e a Constituição. AJURIS-4, 1977. pp. 13/14 e 19/20).

A concepção americana de 1787 , no dizer de EDUARDO GARCIA DE ENTERRÍA, devia supor-se essencial em todas as Constituições escritas, segundo a qual a lei que repugna a Constituição é nula, tal como afirmara o Juiz MARSHALL, em sentença célebre da Suprema Corte. Os sucessos da era napoleônica e da Restauração, com seus reflexos políticos, concorreram para retardar, na Europa, a definitiva consagração de princípios básicos do sistema americano, quanto à supremacia da Constituição e à revisão judicial das leis. A ideologia legalista, veiculada pelo liberalismo, na Europa, confiava ao Parlamento o monopólio da tutela e interpretação da ordem jurídica, reduzindo as funções da magistratura à mera aplicação mecânica e silogística da lei. Nenhum outro órgão, que não o Parlamento, estava habilitado a dar palavra final acerca do significado da lei e da própria Constituição. Daí surgia, naturalmente, a impossibilidade do estabelecimento de qualquer procedimento de controle dos seus atos por outro órgão do Estado (apud NELSON SALDANHA, Legalismo e Ciência do Direito. p. 57; VASCONCELOS DINIZ, Constituição e Hermenêutica Constitucional. pp. 125/126).

2. Entre nós, a influência dos dois sistemas fez-se notar. A Constituição Imperial de 1824 orientou-se no sentido do liberalismo de tendência européia, colocado o Judiciário em uma posição secundária, no confronto com o Legislativo e o Executivo.
Embora a Carta de 1824 , no art. 10 afirmasse que os poderes políticos reconhe cidos pela Constituição do Império do Brasil são quatro: o poder legislativo, o poder moderador, o poder executivo e o poder judicial, bem assim, no art. 151, proclamasse que o poder judicial é independente, certo é que, nessa quadra de nossa história política, ele se limitava a dirimir controvérsias de direito privado e aplicar a lei penal, escapando, por inteiro, ao seu controle, os atos da administração pública e a validade das leis. Já em 1857, JOSÉ ANTÔNIO PIMEN TA BUENO, Marquês de São Vicente, o mais ilustre comentarista da Constituição do Império, anotava: "O poder judicial tem por encargo o domínio, a aplicação das leis que formam o direito particular, a ordem civil, que regulam e compõem os interesses dos indivíduos entre si na qualidade de particulares (...); é o protetor dos direitos e interesses individuais, da propriedade, da liberdade, honra, vida, de tudo o que é caro aos homens como homens; seu poder em vez de ser discricionário é restritamente legal; seus agentes, os magistrados, são perpétuos e independentes; seu processo dirigido sempre pelo direito positivo, circundado de garantias certas, de debates contraditórios e de fórmulas minuciosas, completas, previdentes". E, noutro passo, observa: "Ele não é autorizado a invadir as raias do Poder Legislativo, não tem por isso mesmo direito de decretar decisões por via de disposição geral, e só sim de estabelecêlas em relação à espécie que lhe é subordinada. Não possui jurisdição para decidir questões de ordem administrativa, pois que pertencem à competência exclusiva do go verno" (apud Direito Público Brasileiro e Aná- lise da Constituição do Império. Senado Federal, 1978. pp. 34/35). O controle da constitucionalidade das leis cabia ao Poder Moderador e ao Poder Legislativo, a este último incumbindo velar na guarda da Constituição, interpretar as leis e suspendêlas (Constituição de 1824, art. 15, itens 8 e 9). A independência do Judiciário havia de ser, desse modo, entendida, apenas, numa perspectiva subjetiva, como independência da autoridade judicial, do magistrado, definida pelo mesmo PIMENTA BUENO, como "a faculdade que ele tem, e que necessariamente deve ter de administrar a justiça, de aplicar a lei como ele exata e conscienciosamente entender, sem outras vistas que não sejam a própria imparcial justiça, a inspiração de seu sagrado dever. Sem o desejo de agradar ou desagradar, sem esperanças, sem temor algum. (...)", acrescentando: "A independência do magistrado deve ser uma verdade, não só de direito como de fato; é a mais firme garantia dos direitos e liberdades, tanto civis como políticas dos cidadãos; é o princípio tutelar que estabelece e anima a confiança dos povos na reta administração da justiça; é preciso que o povo veja e creia que ela realmente existe" (op. cit., no 457 , p. 324). TAVARES DE LYRA, em conferência pronunciada em 1926, sobre a Justiça no Império, depois de registrar a posição do Poder Moderador - "a chave de toda a organização política" - a quem se reservava, dentre outros, o poder de "suspender magistrados", acentua: "Mas, em verdade, a subalternidade do Poder Judiciário provinha menos da supremacia do Moderador do que da dependência em que estava do Legislativo e do Executivo, que, identificados por interesses políticos ocasionais, con- 
jugavam quase sempre sua ação para enfraquecê-lo, delimitando-lhe a órbita de atribuições, cerceando-lhe a autonomia, desrespeitando-lhe as garantias de independência. O Executivo sobretudo. As aposentadorias forçadas e as remoções que se seguiam à ascensão dos partidos demonstram o que eram, no Império, a vitaliciedade e a inamovibilidade dos juízes, impedidos, em muitos casos, de interpretar conscienciosamente as leis, que os ministros desvirtuavam na legislação dos avisos". Noutro passo, acrescenta: "Não obstante os excessos e violência a que estava exposta, a magistratura jamais deixou de desempenhar digna e honestamente seu ofício de julgar. Para ela, as decepções não geravam desalentos. Ao contrário, eram incentivo e estímulo para que os seus representantes, quando atirados para as paragens do interior, na faina das derrubadas, contivessem, em justos limites, o poderio dos mandões políticos, tornando-se protetores dos oprimidos, os defensores naturais das liberdades civis, que é patrimônio de toda a nação e sem a qual não existe opinião pública, em última análise a força que legitima os governos nos regimes livres" (apud Instituições Políticas do Império. Senado Federal, 1979. pp. 173/ 174).

3. Com a República, estabeleceu-se um marco fundamental na história do Judiciário brasileiro, que, em sua organização e ação, passou a inspirar-se no liberalismo de vertente norte-americana, desvin-culandose do sistema de orientação continental, e alcançando, aí, em conseqüência, contornos institucionais e funcionais também de Poder Político independente.
CAMPOS SALES, então Ministro da Justiça do Governo Provisório, em Exposição de Motivos ao Generalíssimo DEODORO DA FONSECA, ao propor a criação e organização da Justiça Federal, o que se veio a concretizar no Decreto no 848 , de 11.10.1890, depois incorporado, em seus preceitos gerais, na Constituição de 1891 , proclamava: "A função do Liberalismo do passado foi opor um limite ao poder violento dos reis; o dever do liberalismo na época atual é opor um limite ao poder ilimitado dos parlamentos. Essa missão histórica incumbe, sem dúvida, ao Poder Judiciário, tal como o arquitetam poucos povos contemporâneos e se acha consagrado no presente decreto". E adiante, anotava: "A magistratura que agora se instala, no país, graças ao regime republicano, não é um instrumento cego ou mero intérprete na execução dos atos do poder legislativo. Antes de aplicar a lei, cabe-lhe o direito de exame, podendo dar-lhe ou recusar-lhe sanção, se ela lhe parecer conforme ou contrária à lei orgânica". Noutro passo, asseverou: "Aí está posta a profunda diversidade de índole que existe entre o poder judiciário, tal como se achava instituído no regime decaído, e aquele que agora se inaugura, calcado sobre os moldes democráticos do sistema federal. De poder subordinado, qual era, transforma-se em poder soberano, apto na elevada esfera da sua autoridade para interpor a benéfica influência do seu critério decisivo, a fim de manter o equilíbrio, a regularidade e a própria independência dos outros poderes, assegurando, ao mesmo tempo, o livre exercício dos direitos do cidadão. É por isso que na grande União Americana com razão se considera o poder judiciário como a pedra angular do edifício federal e o único capaz de defender com eficácia a liberdade, a autonomia individual. Ao influxo de sua real soberania desfazemse os erros legislativos e são entregues à austeridade da lei os crimes dos depositários do Poder Executivo".

4. Pois bem, o sistema americano que nos serviu de modelo, ao implantar-se a República, faz mais de um século, assenta no princípio da supremacia da Constituição, à qual se subordinam todos os Poderes - $\mathrm{e}$ na independência do Judiciário, que se manifesta, por primeiro, na prerrogativa eminente de proceder à revisão judicial das leis e dos atos normativos, diante da Constituição, anulando-os quando com esta incompatíveis. Os estudiosos do regime americano, de mais de dois séculos, asseveram que, na virtude que exibe a Constituição de 1787 para dominar crises, reside a sua extraordinária contribuição ao constitucionalismo, cumprindo ver, na judicial review, a fórmula que acaba por garantir à ordem constitucional a estabilidade dela exigida. Ademais disso, a competência para operar, acerca da lei, a chamada judicial review revela manifesto "poder político", porquanto, se este existe no órgão que faz a lei, importa entender, inafastavelmente, estar presente, por igual, no órgão que dispõe de império para declarar-lhe a invalidade. No controle sobre os atos do Legislativo e do Governo evidencia-se o caráter político de que está investido o Judiciário, no desempenho da competência para proclamar a inconstitucionalidade ou invalidade de tais atos. Essa função política, que, em ditos limites, se revela, numa democracia, em que consagrado o controle judicial da constitucionalidade das leis e atos do go- verno, pressupõe, necessariamente, ínsita a nota de independência.

A função jurisdicional, por sua natureza, não pode ser, destarte, visualizada apenas como atividade estritamente de técnica jurídica, de interpretação definitiva do direito positivo, senão que se afirma como prerrogativa eminente da soberania nacional. Por seu intermédio, não só se dirimem, de forma terminativa, os conflitos de interesses e se garantem os direitos e liberdades dos cidadãos, mas é possível, também, opor limite à ação do Governo, da Legislatura e dos próprios Tribunais, se contravier a Constituição ou as leis.

5. De outra parte, qual escreveu EDWARD S. CORWIN, acerca do sistema americano, como os poderes "legislativo" e "executivo", sob a Constituição, o poder "judiciário" também implica certos atributos incidentais ou inerentes. Um deles é a faculdade de interpretar o direito em vigor, seja a Constituição, quer as leis do Congresso ou os precedentes judiciais, com uma autoridade que obriga, constitucionalmente, ambos os ramos do Governo. Noutro passo, acrescenta: "Intimamente ligado a esse atributo do poder judiciário existe outro, o de proferir 'decisões finais'. Quando se confia a um tribunal dos Estados Unidos a determinação de uma questão, seja de direito ou de fato, sua decisão só pode ser revista, constitucionalmente, por um tribunal de instância superior, e não pelos outros dois ramos do Governo ou pelos seus órgãos" (in A Constituição Norte-Americana e seu Significado Atual. Tradução de LÊDA BOECHAT RODRIGUES, pp. 162/ 165). COOLEY, à sua vez, anotou: "Os 
diversos departamentos governamentais são iguais em dignidade e em autoridade que é coordenada, não podendo nenhum deles submeter o outro a sua jurisdição, nem a privar de qualquer porção de seu poder constitucional. Mas o poder judiciário é autoridade suprema na interpretação da Constituição e na interpretação das leis e as suas interpretações devem ser aceitas e observadas pelos outros departamentos". Dessa maneira, diante da decisão judicial definitiva, não cabe opção dos que lhe são destinatários - quer se cuide de particulares, quer de detentores de poder -, no sentido do acatamento ou não do julgado. Por sua natureza, o que se contém na sentença judicial, desde que esta se torne irrecorrível, no âmbito do Poder Judiciário, constitui, na ordem democrática, comando incontrastável, tornando-se, pois, fora de propósito, qualquer indagação ou perplexidade sobre se a autoridade executiva ou legislativa, ou mesmo judiciária de grau inferior, cumprirá a decisão judicial.

Subordinando-se o Judiciário, tal qual sucede com o Legislativo e o Executivo, à Constituição, que sobreleva a todos os poderes, bem de compreender é, destarte que a prerrogativa e a ampla liberdade de interpretar definitivamente o ordenamento positivo, para aplicá-lo, em decisões definitivas, não autorizam o arbítrio dos tribunais e juízes, de molde a decidirem fora dos limites, que lhes traça a razoável compreensão da Constituição e das leis válidas.

No Brasil, a manifestação do Judiciário, como poder político, pelo controle dos atos do Legislativo e do Executivo - ou como entre os autores americanos se deno- mina essa técnica de controle, judicial control (CHARLES BEARD) ou judicial review (EDWARD CORWIN), conforme descrita por MARSHALL, em 1803, em MARBURY versus MADISON -, esse as pecto essencial da independência funcio nal do Judiciário é, entre nós, assim, sem dúvida, obra da República. Segue-se, no particular, também, a inspiração da célebre fórmula - "beyond all reasonable doubt" (acima de toda a dúvida razoável), como condição para declarar a inconstitucionalidade de lei ou de ato executivo, com o que se opera, por igual, o indispensável convívio do princípio da independência com o da harmonia dos poderes políticos da República.

6. Além dessas duas perspectivas de visualização histórica do Judiciário, no Brasil, como poder independente: primeiro, apenas no sentido da independência do magistrado, no regime da Constituição de 1824 (arts. 10 e 151) e assim na fase imperial; depois, no período republicano, já com mais de um século, também, como efetivo poder político, ao deter a prerrogativa do controle judicial dos atos dos outros poderes certo é que a Constituição de 1988 lhe conferiu, de forma expressa, em sua caracterização institucional como poder político independente, mais um traço de significação inequívoca: a autonomia administrativa e financeira, tal como descrita em seu art. 99 e parágrafos.

Da autonomia financeira cuidam os parágrafos do art. 99, firmando-se a competência dos tribunais para a elaboração de suas propostas orçamentárias dentro dos limites estipulados conjuntamente com os demais Poderes na lei de diretrizes orçamen- tárias (Constituição, art. 165, II e $§ 2^{\circ}$, e $99, \S 1^{\circ}$ ), indicando-se, desde logo, os Tribunais federais e estaduais a quem se confere a atribuição do encaminhamento da proposta. Exclui-se, pois, a sujeição das Cortes aos critérios e índices que entendam de arbitrar autoridades do Poder Executivo, quanto às propostas orçamentárias e aos elementos da despesa do Poder Judiciário. Nesse sentido, de resto, afirmou o Supremo Tribunal Federal, em sessão administra tiva de 02.08.1989. De outra parte, o art 168 da Lei Maior, como garantia do Poder determina que os recursos correspondentes às dotações orçamentárias, compreen didos os créditos suplementares e especiais, ser-lhe-ão entregues até o dia 20 de cada mês. No Mandado de Segurança no 21.273 0/160-SP, tive oportunidade de acentuar esse respeito: "A liberação do numerário correspondente às dotações orçamentárias do Poder Judiciário, até o dia vinte de cada mês, nos termos do art. 168, da Constituição Federal, (...), constitui garantia do Po der Judiciário, que há de ser respeitada pelo Poder Executivo, guardando-se, outrossim, o princípio da independência e harmonia dos Poderes do Estado. Não cabe, dessa sorte, ao Poder Executivo, estabelecer datas diversas ou a data que lhe aprouver, cada mês, para liberar os recursos orçamentários referentes ao Poder Judiciário."

Assume, entretanto, especial interes se, no que concerne à indispensável unida de do Poder Judiciário, o ponto relativo à autonomia administrativa. É que, em realidade, no art. 99 aludido, afirma-se que, ao Poder Judiciário, é assegurada autonomia administrativa. Ora, compõem a estrutura do Poder Judiciário, nos dias em curso, no- venta e seis Tribunais: 35 dos Estados e Distrito Federal e 61 da União, aqui incluídos o Supremo Tribunal Federal e os Tribunais Superiores. Já tive ensejo de sinalar que a autonomia administrativa assim preceituada, amplamente, em cláusula constitucional, não se restringe, tão-só, à competência privativa dos tribunais para eleger seus órgãos diretivos e elaborar seus regimentos internos, organizar as secretarias e serviços auxiliares e os dos juízos que lhes forem vinculados, provendo, na forma prevista na Constituição, os cargos de juiz de carreira da respectiva jurisdição, ou para propor criação de novas varas judiciárias, preenchendo os cargos indispensáveis à administração da justiça, concedendo licença, férias e outros afastamentos a seus membros e aos juízes e servidores que lhes forem imediatamente vinculados, competências essas que se conumeram em outras regras específicas (art. 96, I, e alíneas, da Constituição). Em recentes decisões, o Supremo Tribunal Federal afirmou, outrossim, na linha do autogoverno do Poder Judiciário, a competência dos próprios Tribunais de Justiça dos Estados para a nomeação, não só dos juízes de instância inferior, mas de seus membros em vagas destinadas à magistratura de carreira. Por igual, reconheceu a Corte Suprema a competência dos Tribunais para disporem, em seus regimentos internos, sobre a existência do órgão especial a que se refere o art. 93, XI, da Constituição, matéria esta objeto de expressa previsão no Projeto do Estatuto da Magistratura Nacional (art. 6으, I).

Compreendo, entretanto, que essa cláusula constitucional possui abrangência maior. Cumprindo ao Judiciário, enquanto 
Poder Político do Estado, com exclusividade, a execução do serviço público de administração da justiça, importa entender que a Constituição, ao lhe conferir autonomia administrativa e financeira, quis assegurarlhe competência não só para pensar e planejar as estruturas mais convenientes, quais meios, à execução do fim, mas, também, para propor, quando a tanto necessário, aos outros Poderes, as providências que considere indispensáveis, em ordem a dar-se prestação jurisdicional, de maneira mais eficiente e pronta, assegurando o acesso de todos à Justiça. Distintos os planos da atividade jurisdicional e da atividade adminis trativa, no âmbito do Judiciário, é certo que a hierarquia dos graus de jurisdição "nada mais traduz do que uma competência de derrogação e nunca uma competência de mando da instância superior sobre a inferior", na lição dos processualistas, resguardan do-se, desse modo, a independência jurídica e funcional dos magistrados entre si. Não menos exato é, entretanto, que a atividade administrativa, no âmbito do Poder Judiciário, na medida em que se manifesta como atos de administração, há de conceber-se numa perspectiva diferente, tornando viável, inclusive, um amplo plano de aperfeiçoamento do Poder Judiciário brasileiro, em suas dimensões nacional e regional. É, neste ponto, que a unidade do Poder há de discutir-se, para que os mecanismos de sua atuação a revelem, de maneira afirmativa, evitando-se que a pluralidade das autonomias o torne irreconhecível, sem uma fisionomia nacional, que o revele e o projete no concerto das instituições básicas da Nação. Essa unidade pressupõe um espírito comum a informar a ação do Poder Judiciá- rio, modelada em valores marcantes de seu agir, que o identifiquem, perante a sociedade, em todos os recantos do imenso território nacional.

No particular, é certo que a nota de inteira independência há de marcar o exercício da função jurisdicional dos tribunais e juízes, decidindo os magistrados os litígios que lhes são submetidos, de acordo com as respectivas competências, sujeitos, tãosó, à Constituição, às leis e aos ditames de sua consciência. Não é possível compreender, entretanto, que, no desempenho de autonomia administrativa, os órgãos do Judiciário estejam autorizados a desvincularse desses imperativos, adotando decisões a seu talante ou sob inspiração outra que não seja, ainda, a própria de sua consciência de juiz. É exato que, nessa condição de administrador, os Tribunais possuem, também, as prerrogativas inerentes à atividade administrativa, em que os juízos de conveniência e oportunidade se formulam, em plano do poder discricionário, mas, de qualquer sorte, obedientes, sempre, aos princípios de legalidade, impessoalidade, moralidade e publicidade. A autonomia administrativa, como dimensão da independência institucional do Poder Judiciário, não cabe, na sua prática, desfigurar a nobreza da instituição judiciária, máxime, na sua face de respeitabilidade e de pontual cumprimento dos deveres, que a tornam merecedora do acatamento da sociedade e fonte de segurança para os cidadãos, no pleito dos direitos e da liberdade. A autonomia administrativa não legitima, destarte, em nenhuma hipótese, atos do Judiciário, enquanto administrador, contrários à lei ou passíveis de censura sob o ponto de vista ético. $\mathrm{O}$ autogoverno do Poder Judiciário, em se expressando por meio de atos administrativos, não pode deixar, em qualquer instante, de ser atividade, com a marca indelével do magistrado.

A independência institucional do Poder Judiciário revela-se, pois, já nas prerrogativas eminentes do amplo controle judicial dos atos de todos os outros Poderes, na sua expressão jurisdicional, em que se faz presente sinal de poder político, já na atividade administrativa, ao planejar e executar os serviços da justiça e administrar os recursos humanos e materiais disponíveis. Em ambos os planos, o juiz e a lei hão de constituir um par inseparável. Na concepção de projetos que mais convenham à administração da justiça ao povo, manifesta-se, por igual, essa autonomia, insuscetível de ser substituída por critérios ou planos outros do Poder Executivo. O que é do peculiar interesse do Poder Judiciário, di-lo-á, ele próprio, por intermédio de seus órgãos competentes, colimando a boa consecução de seus fins institucionais ou adotando as iniciativas indispensáveis junto aos outros Poderes.

Penso, entretanto, que a unidade do Poder Judiciário constitui, em nosso tempo, tema a merecer reflexão, precisamente, para que, na prática de valores fundamentais, a imagem desse Poder seja nacional. $\mathrm{Na}$ consecução de tal objetivo, entendo que cabe ao Supremo Tribunal Federal tarefa significativa. Se é exato que a Corte Suprema busca manter ou restabelecer o equilíbrio federativo, a independência e harmonia dos demais Poderes, numa missão autenticamente moderadora, não é menos proce- dente que se lhe impõe, também, zelar, na intimidade do Poder Judiciário, pela própria independência deste, nas variadas dimensões, inclusive da autonomia administrativa e financeira, que, em norma expressa, a Constituição lhe assegura (CF, art. 99), coordenando, outrossim, as providências ao pontual cumprimento, pelo Judiciário, enquanto poder nacional, de sua missão maior de administrar justiça. Situado como instância de superposição, em relação a todas as jurisdições do País, em escala maior ou menor, no que concerne à atividade jurisdicional, justifica-se, também, participe, de maneira valiosa, no debate dos problemas administrativos que respeitam à realidade judiciária da Nação e empreste seu concurso no encaminhamento, perante os fóruns mais altos dos outros Poderes, das soluções devidas, como órgão de cúpula do Judiciário. Essa participação do Supremo Tribunal Federal há de fazer-se realmente efetiva, no exame conjunto com os demais órgãos do Poder Judiciário das questões que lhe forem pertinentes, no funcionamento de um Conselho Nacional de Administração da Justiça, cuja criação está proposta no Projeto do Estatuto da Magistratura Nacional, que, em cumprimento ao art. $93 \mathrm{da}$ Constituição, faz alguns anos, o Supremo Tribunal Federal encaminhou ao Congresso Nacional, e elaborado com a contribuição dos Tribunais do País. Nesse Conselho hão de ter voz e voto representantes de todos os ramos do Poder Judiciário nacional.

Com o curso dos anos de vigência do art. 99 da Constituição de 1988, tem crescido minha convicção quanto à necessidade desse Conselho Nacional. Nele encontrará o Poder Judiciário brasileiro, por 
certo, um fórum não só de debates dos altos problemas do Poder, no bom desempenho de sua autonomia administrativa, mas, também, um extraordinário instrumento de sua unidade e de encaminhamento de magnas soluções, presentes representantes de todos os ramos da Justiça brasileira, eliminandose, dessa maneira, desde logo, decisões administrativas isoladas de tribunais, de natureza importante, em conflito, por vez, com a Constituição e as leis.

7. Dessa maneira, a legitimidade do Judiciário enquanto poder político independente decorre, em primeiro lugar, de sua disciplina institucional inscrita na Constituição, em que se prevêem a competência, seus órgãos, forma de investidura de seus agentes, e os princípios fundamentais do respectivo regime jurídico, à semelhança do que ocorre com os outros Poderes que têm todos, em um estado de direito, numa democracia, na Constituição definidos os limites de sua competência e a forma de sua composição. A autoridade permanente dos tribunais e juízes resulta, assim, imediatamente, da Constituição, não sendo derivada de vontade de outro Poder instituído, senão do próprio Poder Constituinte originário, emanação direta da soberania popular, expressa na Lei Fundamental da República. $O$ exercício legítimo da função jurisdicional tem, de outra parte, na Constituição, sua sede e justificativa; daí, com inteira procedência, afirmar-se, também e por isso mesmo, que o primeiro compromisso do magistrado é respeitar a Constituição. A investidura como autoridade judiciária, na forma da Constituição, não confere, entretanto, ao juiz aptidão a decidir, discricionariamente, apenas, por invocação de princípios ideológicos ou de convicções pessoais, deixando à margem a Constituição e a lei válida (isto é, conforme a Constituição), aplicável à espécie. De contrário, seria admitir a substituição do legislador, pelo juiz, com evidente desconsideração ao preceito básico do sistema democrático relativo à separação e harmonia dos poderes, cujo exercício há de dar-se nos limites deferidos na Constituição. Com isso, não diminui a independência do magistrado na sua legitimação para, em solvendo litígios, interpretar a lei, atento a seus fins sociais e aos imperativos do bem comum, que também lhe cumpre promover, no ato de julgar. Nesse sentido, admiravelmente, observou o saudoso Ministro JOÃO LEITÃO DE ABREU:

"Auscultando, em face da dramaticidade inerente ao caso concreto, as pulsações da vida social, o juiz, guardando as palavras da lei, porta-se com certa margem de liberdade na sua aplicação".

Referindo-se ao fato de, em realidade, os juízes, no exercício legítimo de sua função, nunca se terem cingido, no aplicar as leis, a realizar operações de caráter simplesmente lógico-formal, escreveu o insigne jurista:

"A verdade é que, em todos os tempos, o juiz, para dar resposta às exigências da utilidade comum, sempre se deixou guiar por juízos de valor. (...). A sensibilidade apreciativa do juiz preside, comumente, por conseguinte, quer à qualificação dos fatos, que hajam de entrar no silogismo da sentença, quer à eleição do texto legal, que lhe venha servir de apoio.
A juízos de feição axiológica subordina-se, igualmente, a escolha, em cada hipótese, do método de interpretação a ser utilizado, porquanto não é possível justificar-se, por via puramente lógico-formal, o emprego, aqui, de um método e ali de método diverso para aplicação do direito". (in A Função Política do Judiciário. Correio do Povo, Porto Alegre, publ. 14.09.1965. p. 4)

8. Compreendida, nessa projeção, em sua natureza, a independência do Judiciário, cumpre visualizá-la em sua perspectiva teleológica, enquanto instrumento de efetiva realização da cidadania e de real garantia dos direitos.

Em verdade, o exercício da plenitude da cidadania não se dá, se não houver procedimentos eficientes a tornarem reais os direitos e prerrogativas que lhe são ínsitos e formas eficazes para exigir essa garantia, sem as quais ela se torna vã e ilusória.

Constitui, nesse sentido, questão de primeiro plano à cidadania a oferta de justiça, pelo Estado, compatível com a procura e a necessidade decorrentes de uma convivência social, cada vez mais comple$\mathrm{xa}$, o que se acentua, significativamente, nos países de desequilíbrios sociais graves. A visibilidade social que os meios de comunicação de massa conferem, ademais, ao serviço público essencial de administração da justiça, em nossa época, particularmente, no revelar suas deficiências, torna, sempre mais, abertos o debate e os estudos, de diversificadas naturezas, sobre essa província da ação do Estado, sobre a estrutura e os órgãos do Poder Judiciário, sobre a formação e o recrutamento dos magistrados, sobre a opinião do povo a respeito dos ser- viços judiciários, estendendo-se, hoje, as indagações, inclusive, a domínios, até aqui, impenetráveis, acerca das próprias motivações das sentenças, das ideologias dos juízes e dos limites da ação judicial, diante das omissões ou das deficiências do processo legislativo, e sobre o ritmo do andamento dos feitos, em suas várias fases.

O serviço público da justiça, decerto, ao lado dos demais serviços do Estado, há de concorrer, pela excelência de seu de. sempenho, aos fins maiores da realização do bem comum e da cidadania. Não pode, dessa maneira, a prestação jurisdicional deixar de ter presente o caráter prático dos resultados a obter, a natureza e os fins das normas válidas, que cabe aplicar, editadas, em princípio, para ordenar a convivência, com objetivo de alcançar a proteção e segurança dos direitos dos indivíduos, o equilíbrio, a paz e a harmonia social. Confiado esse serviço público a um dos Poderes do Estado, bem de entender é, destarte, que a administração da justiça não constitui, em toda sua universalidade, como antes referi, atividade estrita e exclusivamente de técnica jurídica, de ciência do direito. Se a missão de julgar deve ser cumprida, com inteira indiferença, em relação aos poderosos, jamais poderá ser, entretanto, cega aos interesses dó bem comum. Por isso mesmo, o Juiz, de nossos dias, órgão de um Poder do Estado independente, há de ter presente a realidade do mundo social e econômico em que vive, ao voltar-se para a concretude do caso que lhe incumbe dirimir, atento aos fins sociais a que a lei se dirige.

9. Nessa linha, dentre os princípios fundamentais da ordem democrática, esta- 
beleceu-se, entre nós, o compromisso pelo Estado do controle jurisdicional: a lei não excluirá da apreciação do Poder Judiciário lesão ou ameaça a direito (Constituição de 1988, art. 5ํ, XXXV). Não há, nessa norma, simples promessa, senão que, nela, já se insere, de maneira definitiva, traço marcante da fisionomia do Estado, proveniente do pacto fundamental, que se expressa, basicamente, na garantia maior da inafastabilidade da tutela, por um Poder Judiciário independente, dos direitos e da liberdade dos cidadãos.

Em virtude de tudo isso, não é admissível pensar em uma ordem constitucional democrática sem ter presente o processo, na medida em que é instrumento indispensável à administração e realização da justiça, à busca da verdade nos conflitos de interesses, bem assim enquanto meio de efetiva garantia da liberdade, da defesa dos direitos violados ou ameaçados e, ainda, de ação política estatal. De igual modo, não é cabível visualizar o processo, senão a partir das linhas fundamentais que o ordenamento constitucional lhe confere, da conformação que o Estatuto Maior empresta a seus institutos básicos e ao respectivo funcionamento. Como anotou HABSCHEID, "os sistemas políticos se refletem na norma constitucional e têm um efeito direto sobre as bases do direito processual" (in As Bases do Direito Processual Civil, nº 1, esp. p. 119). $\mathrm{Na}$ esteira desse pensamento, escreve CÂNDIDO DINAMARCO: "O processo que nos serve hoje há de ser o espelho e salvaguarda dos valores individuais e coletivos que a ordem constitucional vigente entende de cultuar. Os princípios que ela inclui não podem ter no presente a mesma extensão e significado de outros tempos e regimes políticos, apesar de eventualmente inalterada a formulação verbal. $\mathrm{O}$ que há de perene nos princípios é a idéia-mestra que cada um contém; e eles são sujeitos a variações histórico-culturais e políticas no tempo e no espaço, no tocante à sua extensão e à interpretação que merecem dentro de cada sistema constitucional" (apud A Instrumentalidade do Processo. $2^{\text {a }}$ ed., pp. 32/ 33).

$\mathrm{Na}$ atualidade, o processo, na condição também de eficaz instrumento de ação política estatal, não pode deixar de receber o influxo do universal reclamo de justiça social, que é a tônica de nossa época, e se põe entre os objetivos fundamentais da República, ao pretender "construir uma sociedade livre, justa e solidária", afirmando "a dignidade da pessoa humana" (Constituição, arts. 2 , III, e 3으, I). A existência de instrumentos, que tornem reais - e não meramente simbólicos - os direitos do cidadão comum, é imperativo de um Estado Democrático de Direito, tal como o concebe a Constituição de 1988. O processo, enquanto instrumento de realização da justiça, que é um valor eminentemente social, não pode ser visualizado como meio exclusivo ou predominante de utilidade privada, modo privato. $O$ eminente professor gaúcho GALENO LACERDA, discorrendo sobre a "abertura para o social" como uma das marcas mais características do Direito brasileiro em nosso tempo, registrou que essa nota "supera, em definitivo, a formação individualista que sempre caracterizou a cultura jurídica da Europa continental retratada, de modo geral, em nossas instituições" (in Eficácia da Prestação Jurisdicional no Atendimento às Demandas Sociais, apud AJURIS, vol. 59, p. 49). Certo está, de outra parte, que nem a ação nem a defesa podem ser consideradas na exclusividade de um ato. Realizar-se-á, assim, a plenitude do controle jurisdicional, de maneira justa, somente quando houver atenção ao devido processo legal, à garantia da participação real no feito de demandante e demandado, e à observância do contraditório, "mediante uma distribuição eqüitativa de meios e possibilidades processuais" entre as partes. Registrou, nesse sentido, com inteira propriedade, ADA PELLEGRINI GRINOVER, em Novas Tendências do Direito Processual. 1'a ed., 1990, p. 11: "A plenitude e a efetividade do contraditório indicam a necessidade de se utilizarem todos os meios necessários para evitar que a disparidade de posições no processo possa incidir sobre seu êxito, condicionando-o a uma distribuição desigual de forças. A quem age ou se defende em juízo devem ser asseguradas as mesmas possibilidades de obter a tutela de suas razões".

De outro lado, na pugna judiciária não é suficiente se desenhe mera igualdade formal na relação processual, como a entendia bastante a antiga concepção privatística do processo, para propiciar uma justa solução das demandas. Distante de mais de um século está a quadra em que exacerbado individualismo reduzia a limites estreitos a área de atividade do juiz, aparecendo as demandas como de interesse exclusivo dos litigantes, intervindo o Estado, tão-só, para que as regras fossem observadas pelos contendores e não se fizesse justiça pelas próprias mãos. Tornada pre- dominante, porém, a concepção publicística do processo, não apenas cresceu de ponto a importância da jurisdição no quadro das funções do Estado, como a finalidade do processo deixou de ser exclusivamente a proteção dos direitos subjetivos, passando a garantir ou a atuar o direito objetivo, o que seria de interesse do Estado e não apenas dos particulares.

Nessa linha do pensamento políticofilosófico, recolhido pelo constitucionalismo pátrio, foram aumentados os poderes do juiz, na cena judiciária, que deixou de ser espec. tador quase inerte da batalha judicial, cabendo-lhe impulsionar o andamento das causas, determinar provas, reprimir a máconduta das partes, conhecer, ex officio, de circunstâncias, até então dependentes de alegação do interessado. E nada parece, todavia, ter ocorrido, como antes se supunha, em prejuízo da imparcialidade do magistrado. Cumpre, nesse sentido, por primeiro, ter presente que o que bem interessa é a verdade na decisão final. $O$ triunfo na luta judiciária não deve resultar de pequenos lapsos na atividade do adversário, nem convém à Justiça que as demandas se inutilizem por preliminares de natureza processual, mas, sim, que se decidam os conflitos no seu mérito, pela efetiva existência do direito ao lado do vencedor. Manter o juiz, em relação aos mémbros do Ministério Público, advogados, procuradores judiciais e defensores públicos, que se hão de ter como efetivos colaboradores na administração da Justiça (Constituição, arts. 127, 131, 132, 133 e 134), a mais ampla abertura, prestando-lhes, inclusive, se necessário, esclarecimentos, chamando a atenção dos litigantes para aspectos das causas não suficientemen- 
te elucidados, alertando-os, outrossim, para circunstâncias descuidadas, por um ou outro dos demandantes, mas que podem ser conhecidas, ex officio, pelo magistrado, não constitui, por si só, quebramento da imparcialidade do julgador, mas representa, isto sim, forma de favorecer o andamento das causas e a justiça das decisões. Não há, inclusive, o juiz de recear que essa atividade esclarecedora denuncie sua opinião sobre certos pontos menores ou secundários do processo, pois o derradeiro desate pende sempre da concorrência de uma pluralidade de fatores. Na condução do processo, contribui, desse modo, o magistrado para que, da atuação do direito objetivo, ocorra, quanto possível, a realização efetiva da justiça, no desate das controvérsias. Não é possível, ademais, deixar, aqui, de ter presente esta lição de ADA PELLEGRINI GRINOVER, em seu Processo Constitucional em Marcha, p. 8, item 2:

"Desse modo, as garantias constitucionais do devido processo legal convertem-se, de garantias exclusivas das partes em garantias da jurisdição, e transformam o procedimento em um processo jurisdicional de estrutura cooperatória, em que a garantia de imparcialidade da jurisdição brota da colaboração entre partes e juiz. A participação dos sujeitos no processo não possibilita apenas a cada qual aumentar as possibilidades de obter uma decisão favorável, mas significa cooperação no exercício da jurisdição. Para cima e para além das intenções egoísticas das partes, a estrutura dialética do processo existe para reverter em benefício da boa qualidade da prestação jurisdicional e da perfeita aderência da sentença à situação de direito material subjacente."
Todos esses aspectos ligados à efetividade do processo concernem, à evidência, também, ao tema ainda mais amplo da "efetividade da prestação jurisdicional", certo ser o processo instrumento da jurisdição, meio de efetivação das garantias cons titucionalmente asseguradas aos cidadãos na defesa da liberdade e dos direitos, violados ou ameaçados. A jurisdição, prerrogativa eminente da soberania nacional, exercita-se, em princípio, por um dos Poderes do Estado, nos limites definidos na Constituição. Se não pode a prestação jurisdicional prescindir do processo, a este, entretanto, não se limita, nem nele se exaure sua complexa problemática.

Nessa linha de considerações, não é possível deixar de ter como básico que a plena realização de um Judiciário, institucionalmente independente, com autonomia administrativa e financeira, é condição indispensável à efetividade da prestação jurisdicional. Referindo-se às garantias do processo, MAURO CAPPELLETTI arrola "o direito a um juiz imparcial, o que comporta, entre outras coisas, a garantia da independência da magistratura em face do poder político, porque não há verdadeira função jurisdicional onde o juiz não seja tertius super partes" (in Problemas de Reforma do Processo Civil nas Sociedades Contemporâneas", apud Revista de Processo, no 65, p. 129).

Exsurge, doutra parte, como decorrência natural, que não é possível pensar em um Estado Democrático de Direito, entre cujos fundamentos se alinham a cidadania e a dignidade da pessoa humana, e sob a égide da justiça social, sem assegurar a tutela jurisdicional a todos os cidadãos, afastada qualquer discriminação, inclusive, de fortuna. Põe-se, destarte, no plano da efetividade da prestação jurisdicional, a garantia, em concreto, do acesso efetivo à jurisdição, por todos - vale ressaltar, inclusive, pelos pobres e necessitados -, na defesa de seus direitos e da liberdade, quando violados ou ameaçados. Constitui, pois, tal ponto, postulado central dessa ordem, que aos Poderes do Estado cumpre diligenciar na plena consecução. Acerca desse tema, MAURO CAPPELLETTI anota que o acesso à justiça pode, hoje, ser encarado como o requisito fundamental - "o mais básico dos direitos humanos" - de um sistema jurídico moderno e igualitário que pretenda garantir, e não apenas proclamar, os direitos de todos" (in Acesso à Justiça, 1978, MAURO CAPPELLETTI e BRYANT GARTH, tradução de ELLEN GRACIE NORTHFLEET, p. 12).

Em verdade, superada está a época em que o direito ao acesso à proteção judicial significava, essencialmente, o direito formal do indivíduo agravado de propor ou contestar uma demanda, não constituindo preocupação do Estado, neste plano, afas tar a "pobreza no sentido legal" - a incapacidade que muitas pessoas têm de utilizar plenamente a Justiça e suas instituições. Nessa linha, observa MAURO CAPPELLETTI: "A justiça, como outros bens, no sistema do laissez faire, só podia ser obtida por aqueles que pudessem enfrentar seus custos; aqueles que não pudessem fazêlo eram considerados os únicos responsáveis por sua sorte. $\mathrm{O}$ acesso formal, mas não efetivo, à justiça, correspondia à igualdade apenas formal, mas não efetiva" (op. cit., $p$. 9). À medida, entretanto, que a visão indi- vidualista dos direitos, refletida nas "declarações de direitos", dos séculos XVIII e XIX, foi se modificando, com o movimento no sentido de se reconhecerem, também, os direitos e deveres sociais dos governos, comunidades, associações e indivíduos, assegurando-se, nas modernas constituições, entre outros, os direitos ao trabalho, à saúde, à segurança material e à educação - o direito ao acesso efetivo à justiça vem logrando particular atenção, como de importância capital entre os novos direitos individuais e sociais, uma vez que a titularidade de direitos é destituída de sentido, na ausência de mecanismos para sua concreta reivindicação. O Estado democrático encontra-se preso a seus jurisdicionados pelo dever de garantir-lhes o regular exercício de seus direitos conquistados, quanto de facilitar-lhes a reintegração ou a defesa de direitos violados, ou ameaçados, ou ainda a reparação de lesões oriundas de atos ilícitos, bem assim de proporcionar-lhes condições de realizar a dignidade da pessoa humana.

Nessa ordem, as preocupações com o acesso efetivo à justiça, por todos, inclusive pelos menos favorecidos da fortuna, tornaram-se, nas últimas décadas, de uma forma mais intensa, questão, ao mesmo tempo, do interesse da ciência do direito, quanto da sociologia jurídica. As relações entre o processo civil e a justiça social, entre a igualdade jurídico-formal e a desigualdade sócioeconômica, ganham, neste plano, significativas dimensões. A função do Poder Judiciário cresce, em conseqüência, de interesse, não só ao saber dos profissionais do direito, mas, também, relativamente ao domínio da sociologia jurídica. 
10. Nessa linha, estudos de natureza sociológica, no campo da administração da justiça, evidenciam que dificuldades de todas as ordens cercam os pobres e necessitados, quer as econômicas, quer as condicionantes sociais e culturais, constituindo, todas elas, obstáculos reais ao acesso à Justiça. Em razão disso, lamentavelmente, são milhares (e cada vez maior se torna o número) os estados de insatisfação que se perpetuam e se convertem em decepções permanentes ou em casos de violência, ou procuram soluções aos conflitos, à margem das estruturas e dos órgãos do Poder Judiciário, porque as pessoas não se animam ou não podem litigar em juízo, nem logram meios a fazê-lo. Disso resulta, em conseqüência, lhes ficar distante o acesso à tutela jurisdicional, que o Estado moderno lhes promete como um dos princípios fundamentais da ordem democrática. Incompatível com a fisionomia e as metas do Estado de Direito, realmente democrático, sob a égide da justiça social, é não assegurar tutela jurisdicional a todos os cidadãos, notadamente, quando essa discriminação se dá por razões de fortuna.

Há, no concernente a esse tema, no Brasil, longa tradição constitucional - que remonta à Carta Política de 1934 (art. 113, inc. 32) -, bem assim legal e jurisprudencial, reconhecendo-se a obrigação do Estado de prestar assistência judiciária aos necessitados. Esteve o constituinte de 1988, destarte, sob a melhor inspiração de justiça social, ao emprestar acertado realce à matéria, prevendo, inclusive, no art. 134, da Lei Mag. na, entre as instituições essenciais à função jurisdicional do Estado, a Defensoria Pública, com a incumbência de realizar o ser- viço público de assistência jurídica integral e gratuita aos que comprovarem insuficiência de recursos, defendendo-os, em todos os graus de jurisdição. Trata-se, assim, de orientar e assistir os necessitados, na forma do art. 5, LXXIV, da Constituição, em juízo ou fora dele, em que haverá, também, espaço às atividades de autêntica educação para o exercício dos direitos e prerrogativas da cidadania e para a solução extrajudicial de conflitos. Da boa organização e funcionamento dos serviços das Defensorias Públicas, da União, do Distrito Federal e, especialmente, dos Estados, resultará, de modo inequívoco, contribuição inestimável à administração e efetiva democratização da Justiça, no País. Há, é exato, milhares de conflitos não trazidos, ao exame do Poder Judiciário, particularmente, pequenas causas, insatisfações não resolvidas ou, por vezes, dúvidas acerca de direitos, que atormentam pessoas desamparadas da fortuna e sem condições de acesso a escritórios de advocacia. Quantos conflitos de vizinhança, querelas provenientes de incidentes de pequena monta, que acabam, desnecessariamente, em questões que, ou não se resolvem por simples falta de uma orientação, ou degeneram em atos de violência ou dissídios de profundidade! Organizadas as Defensorias Públicas, como ordena a Cons tituição, com profissionais do Direito, de alta competência, selecionados em concurso público, provendo cargos de carreira, com garantias funcionais de independência no exercício das funções, afastados de preocupações com a advocacia particular, mas remunerados condignamente, como se impõe, bem de ver é que se abrem amplas perspectivas de assistência aos necessitados, esclarecendo-lhes os direitos e as obrigações, em consultas regulares, inclusive com escritórios localizados em bairros da periferia das grandes cidades, prevenindo-se, em conseqüência, também, centenas de ações desnecessárias, realizando-se conciliações, orientando-se, superiormente, soluções no âmbito da família, na proteção a menores e incapazes, na defesa dos consumidores, dentre tantas outras providências, que a boa organização das Defensorias Públicas e a experiência de seu funcionamento hão de trazer. No que concerne à defesa, em Juízo, dos direitos e liberdades dos pobres, é de esperar, com o exercício efetivo dos defensores públicos, dedicados com exclusividade a esse múnus, exista patrocínio competente, dedicado, atento, evitando-se que a desigualdade sócioeconômica, por vezes, existente entre as partes, acarrete, também, a desigualdade na sustentação das respectivas razões e defesas no processo. A Defensoria Pública, como instituição essencial à função jurisdicional, alcança, desse modo, status constitucional, a par de outras instituições contempladas no mesmo Capítulo da Lei Fundamental (Ministério Público, Advocacia-Geral da União e dos Estados) e dos advogados.

Com propriedade, acentua JOSÉ AFONSO DA SILVA, quanto ao novo sistema constitucional, no particular: "Os Estados não têm a faculdade de escolher se instituem e mantêm, ou não, a Defensoria Pública. Trata-se de instituição já estabelecida para eles na Constituição $\mathrm{Fe}$ deral, sujeita até mesmo a normas gerais a serem prescritas em lei complementar federal para a sua organização em cada Estado, em cargos de carreira, providos, na classe inicial, mediante concurso público de pro- vas e títulos, assegurada a seus integrantes (...) a garantia da inamovibilidade e vedado o exercício da advocacia fora das atribuições institucionais." E acrescenta: "Não satisfaz aos ditames do art. 134 a simples criação ou manutenção de Procuradoria de Assistência Judiciária, subordinada à Procuradoria-Geral ou à Advocacia-Geral. A Constituição considera a Defensoria Pública uma instituição essencial à função jurisdicional, destinada à orientação jurídica e à defesa, em todos os graus, dos necessitados, na forma do art. 5o, item LXXIV. Se é uma instituição e ainda sujeita a normas gerais de lei complementar federal, a toda evidência, não pode ser órgão subordinado ou parte de outra instituição, que não ao próprio Estado. (...)" (in Curso de Direito Constitucional Positivo. $5^{\mathrm{a}} \mathrm{ed}$., pp. 533/534).

11. Outro ponto que considero da maior significação, no que concerne à independência do Judiciário, como poder político, é o sistema de controle de seus atos. A atividade administrativa e financeira do Poder Judiciário está sujeita à fiscalização contábil, financeira, orçamentária, operacional e patrimonial, como os demais Poderes, na forma dos arts. 70 a 75 da Constituição, pelo Tribunal de Contas competente. Tenho compreensão, todavia, no que respeita à atividade jurisdicional, de que 0 resguardo da independência do Judiciário, no particular, se dá, desde que se exercite, na intimidade do Poder, a disciplina desses atos, como deflui, outrossim, da parte final da letra $b$ do inc. I do art. 96 da Constituição, em que se estabelece competir, privativamente, aos tribunais velar "pelo exercício da atividade correicional respec- 
tiva". Em tal linha de entendimento, sempre tive, ad exemplum, o Conselho Nacional da Magistratura, previsto na Emenda Constitucional $\mathrm{n}^{\mathrm{o}} 7$, de 1977, e disciplinado na Lei Orgânica da Magistratura Nacional (Lei Complementar no 35/79), composto de sete Ministros do Supremo Tribunal Federal, como órgão disciplinar compatível com a independência do Judiciário, enquanto Poder Político. Não havia, nele, como sucede nos Países, onde a independência do Judiciário não se reconhece, como Poder Político, representantes do Executivo ou do Legislativo, ou mesmo de outros órgãos ou entidades da sociedade civil. Cabia-lhe conhecer de reclamações contra membros de Tribunais, federais ou estaduais, sem prejuízo da competência censória das respectivas Cortes, podendo avocar processos disciplinares contra juízes de primeiro grau e, em qualquer caso, "determinar a disponibilidade ou a aposentadoria de uns e outros, com vencimentos proporcionais ao tempo de serviço" (Emenda Constitucional no 1 , de 1969 , art. $120, \S 1$, , na redação da Emenda Constitucional $\mathrm{n}^{\mathrm{0}}$ 7/77), disciplinando a Lei Orgânica da Magistratura Nacional arts. 50 a 60) o devido processo legal, com ampla garantia de defesa e sigilo. Os juízes, de qualquer grau, possuem deveres e proibições, ao lado de direitos e prerrogativas. A existência dos órgãos censórios e disciplinares, no âmbito dos Tribunais, atende aos aspectos da disciplina judiciária, notadamente, em primeira instância. Não mais contemplado na Constituição de 1988 - Conselho Nacional da Magistratura, não existe, assim, no regime vigorante, órgão de âmbito nacional, para o exercício de atividade disciplinar, de referência aos membros de Tribunais. Estão estes, é certo, nos crimes comuns ou de responsabilidade que pratiquem, sujeitos a processo e julgamento, perante os Tribunais a que se refere a Constituição: os membros dos Tribunais Superiores, no Supremo Tribunal Federal (art. 102, I, c); os desembargadores dos Tribunais de Justiça dos Estados e do Distrito Federal, os juízes dos Tribunais Regionais Federais, dos Tribunais Regionais Eleitorais e do Trabalho, no Superior Tribunal de Justiça (art. 105, I, letra a); os juízes dos Tribunais de Alçada e dos Tribunais de Justiça Militar dos Estados, que os possuem, no Tribunal de Justiça do mesmo Estado. Já os Tribunais Regionais Federais são competentes para processar e julgar, originariamente, os juízes federais de primeiro grau, da área de sua jurisdição, incluídos os da Justiça Militar e da Justiça do Trabalho, nos crimes comuns e de responsabilidade, ressalvada a competência da Justiça Eleitoral ( $C F$, art. 108, I, a), e os Tribunais de Justiça dos Estados e o do Distrito Federal, os juízes respectivos de primeira instância (CF, art. 96 , III). Os Ministros do Supremo Tribunal Federal são processados e julgados, nos crimes comuns, no próprio Tribunal (CF) art. 102 , $\mathrm{I}, b)$, e nos crimes de responsabilidade, perante o Senado Federal (CF, art. 52, II), hipótese em que funcionará como Presidente o do Supremo Tribunal Federal, tal como sucede no julgamento do Presidente e VicePresidente da República, em crimes de responsabilidade, e dos Ministros de Estado, em delitos da mesma natureza "conexos com aqueles" (CF, art. 52, parágrafo único). Releva, ainda, notar que os magistrados, por interesse público, poderão ser removidos, postos em disponibilidade e aposentados, por decisão do respectivo Tribunal, assegurada ampla defesa (CF, art. 93, VIII), regra que torna possível, assim, à própria Corte afastar, pelo mesmo fundamento, também, qualquer de seus membros. Certo é que, garantida aos interessados no processo, ou ao Procurador-Geral da Justiça do respectivo Estado, ou ao Procurador-Geral da República, ou ao Presidente do Conselho Federal ou de Conselho Seccional da Ordem dos Advogados do Brasil, a reclamação, afirmava-se, no funcionamento do Conselho Nacional da Magistratura, prin cípio de superior interesse na ordem democrática, em que todos os titulares de poder são igualmente responsáveis por seus atos e não almejam impunidade. Sempre entendi que o Conselho Nacional da Magistratura, pela forma sigilosa com que resguardava a dignidade do membro de Tribunal, federal ou estadual, acusado, durante a apuração dos fatos - "por manifestamente negligente no cumprimento dos deveres do cargo; de procedimento incompatível com a dignidade, a honra e o decoro de suas funções; ou de escassa ou insuficiente capacidade de trabalho, ou cujo proceder funcional seja incompatível com o bom desempenho das atividades do Poder Judiciário" (LOMAN, art. 56) - e, inclusive, porque, distante das paixões por vezes envolventes do caso, era órgão que não atentava contra a independência do Judiciário, federal ou estadual, nem contra as garantias da magistratura, as quais não conferem aos atos dos juízes inviolabilidade ou perpétua impunidade, se contrários à lei ou aos deveres do cargo. $\mathrm{Nem}$ isso podem desejar os magistrados, perante os princípios fundamentais da ordem democrática. De outra parte, ainda, a autonomia dos Estados-membros não era atingida, em face da natureza e posicionamento de sua Justiça, na unidade do Poder Judiciário nacional, tal como sucede com a eventual reforma das decisões dos Tribunais estaduais, pelo Supremo Tribunal Federal, e, hoje, também, pelo Superior Tribunal de Justiça.

Cuida-se, no Projeto do Estatuto da Magistratura, a par da definição do regime disciplinar dos juízes, da criação de órgão nacional que desempenhará tarefas de significativa importância para o bom desempenho do Poder Judiciário, inclusive no que concerne à unidade de sua ação. Prevê-se, nesse sentido, como antes referido, o funcionamento do Conselho Nacional de Administração da Justiça. Somente por emenda constitucional será possível conferir a esse Conselho competência disciplinar.

Se se fazem convenientes à organização e bom desempenho da magistratura órgãos censórios e de fiscalização dos serviços de administração da justiça, da atividade jurisdicional, compostos na intimidade do Poder Judiciário e por autoridades deste, não tenho, todavia, como compatível com a independência institucional do Judiciário, como Poder Político, que esses órgãos se integrem, também, por autoridades estranhas à organização judiciária nacional, por mais elevados hierarquicamente sejam os dignitários dos outros Poderes que se designem ou os representantes de outras entidades ou segmentos da sociedade civil, inclusive de advogados ou do Ministério Público. A independência dos juízes, no exercício de sua atividade de distribuir jus. tiça, à evidência, não os torna intocáveis; 
ao contrário, órgãos de um dos Poderes do Estado, cumpre-lhes dar contas dos serviços que lhes incumbe prestar, com probidade e eficiência. Integram-se, todavia, em uma estrutura hierárquica. Seus atos estão sujeitos a recursos e reclamações previstos na Constituição e nas leis. Não é possível, no interesse dos cidadãos, cujos direitos, liberdades, garantias e prerrogativas são amparados, precisamente, pela ação independente dos magistrados e dos tribunais, que órgãos estranhos ao Poder Judiciário ou autoridades não judiciárias logrem condições de exercer qualquer forma de influência ou pressão no ânimo dos julgadores, já pela fiscalização do merecimento das decisões, já pela aferição de seu conteúdo, com base em razões de conveniência política ou, o que será ainda pior, por fundamentos ideológicos. Certo é que existem órgãos censórios, nos Tribunais, abertos a queixas das partes pelo procedimento dos magistrados. As Cortes, a seu turno, quando solicitadas, prestam à opinião pública esclarecimentos sobre seus atos e de. cisões. Os julgamentos são públicos e fundamentadas todas as decisões, inclusive as administrativas (Constituição, art. 93, IX e X). Não será cabível, entretanto, que se quebre tradição secular de independência do Poder Judiciário brasileiro, sujeitando-o a formas expressas ou larvadas de influência ou pressão externas, de qualquer natureza ou proveniência. Já em 1857, na obra referida, PIMENTA BUENO acentuava: "Tirai a independência ao poder judiciário, e vós lhe tirareis sua grandeza, sua força moral, sua dignidade, não tereis mais magistrados, sim comissários, instrumentos ou escravos de um outro poder. (...). Não é pois por amor, ou no interesse dos juízes, que o princípio vital de sua independência deve ser observado como um dogma, é sim, por amor dos grandes interesses sociais" (op. cit., p. 324).

12. Compreendo, na linha dessas sucintas observações, destarte, que não cabe em reforma constitucional, em que presentes as limitações materiais do art. $60, \S 4^{\circ}$, da Constituição, a criação, em nossa ordem jurídica, de órgão de controle do Poder Judiciário, ou criado no âmbito de qualquer dos outros Poderes, ou integrado por autoridades desses Poderes, ou de qualquer deles, ou ainda, com representantes de instituição não pertencente ao Poder Judiciário, ou de membros integrados, nesse órgão, sem a participação do Judiciário. Afetada ficará, em qualquer dessas hipóteses, a independência do Poder Judiciário e, assim, violada a cláusula pétrea da separação dos Poderes, ut art. 60, $\S 4^{\circ}$, III, da Lei Maior. Com esta compatível é, entretanto a existência de órgão de controle dos atos do Judiciário, inclusive de natureza disciplinar, quer no plano da União, quer no dos Estados, ou de âmbito nacional, desde que integrado no Poder e composto exclusivamente por magistrados, ou, ao lado destes, por não-magistrados, desde que investidos, nas funções, pelo Poder Judiciário. Somente assim o funcionamento do Poder Judiciário poderá ficar imune a influências dos outros Poderes, com evidente prejuízo à boa prestação jurisdicional, que repugna quaisquer formas de coação ou ameaça aos juízes ou tribunais, expressas ou larvadas, eis que acabam por afetar, imediata e diretamente, a independência do Judiciário, nas várias dimensões aludidas e, assim, por igual, con correm à descaracterização da fisionomia de nosso sistema político que possui, no primado da Constituição e na independência do Judiciário, conotações essenciais. Os magistrados devem ter condições de guardar a lúcida compreensão de sua independência, não estando sujeitos, no exercício do grave múnus, senão à ordem constitucional e legal, bem assim aos ditames de sua consciência, responsáveis todos perante a Pátria, cujo cumprimento dos deveres há de se manifestar no exercício diuturno das funções, com integridade e amor à causa da Justiça, sem temor algum, nem desejo de decidir para agradar ou desagradar a quem quer que seja.

Não tenho, todavia, como contrárias à independência do Judiciário, ou atentatórias às cláusulas pétreas do art. 60 , $\S 4^{\circ}$, da Constituição, mudanças em dispositivos da Lei Magna, tendentes a tornar mais ágil a prestação jurisdicional pelos diversos órgãos do Poder, notadamente com a eventual redistribuição de competências entre Tribunais ou as Justiças da União e dos Estados. Por igual, diante das conclusões anteriores, não vejo limitações materiais à existência de órgãos compostos na intimidade do Poder - e integrados ou só por membros da Corte Suprema, como era o antigo Conselho Nacional da Magistratura, ou também com representações de magistrados de diversos tribunais e ramos da Justiça da União e dos Estados, ou ainda, ao lado desses, com não-magistrados, desde que investidos, no órgão, pelo Poder Judiciário -, com finalidades disciplinares ou de coordenação administrativa, na bus. ca de sua unidade de ação, do aperfeiçoamento e modernização de seus serviços, possibilitando-se, destarte, tornar a autonomia administrativa um instrumento eficiente à melhoria dos serviços da Justiça ao povo, a serem prestados, pelos magistrados, com responsabilidade e independência.

13. São essas algumas reflexões que trago nesta Aula Magna, quanto às dimensões da independência do Judiciário como poder, sua legitimidade e controle, em face dos preceitos fundamentais da ordem jurídica vigente, definidos na Constituição de 1988. Penso, no particular, que, sendo valor essencial à ordem jurídica democrática a instituição judiciária, preservá-la é imperioso, se se pretende consolidar a democracia, como forma de convívio social e marca fundamental de nosso sistema político. $\mathrm{E}$ fiador constante da garantia dos direitos e da liberdade dos cidadãos, o Judiciário quer e há de aperfeiçoar-se, com as mudanças que se fazem necessárias, para servir, sempre mais, à Nação. Sua independência constitui, entretanto, bem indisponível do povo. Muito obrigado. 